\title{
Incidence of carcinoma in situ of germ cells in contralateral testis of men with testicular tumours
}

\author{
JゆRGEN G BERTHELSEN， NIELS E SKAKKEBAEK， PETER MOGENSEN， BENT L SØRENSEN
}

British Medical fournal, 1979, 2, 363-364

\section{Summary and conclusions}

Biopsy specimens from the contralateral testicle in $\mathbf{5 0}$ consecutive patients with germinal testicular cancer were examined for carcinoma in situ. Three out of 21 men with seminomas and one out of 29 with other types of germinal cancer $(8 \%)$ had carcinoma in situ in the contralateral testicle without any clinical signs. One of these men developed early invasive germ-cell cancer 46 months after carcinoma in situ was first diagnosed. The others have been followed up for less than a year without signs of tumour growth.

If these results are confirmed routine biopsy of the contralateral testicle in patients with germinal cancer may be indicated.

\section{Introduction}

Men with germinal testicular tumours run a significantly increased risk of developing cancer of the contralateral testis. The second tumour may present itself at the time of operation or be diagnosed up to 25 years later. ${ }^{12}$ Carcinoma in situ of the testis $^{3-6}$ may precede the second tumour and be asymptomatic at the time of operation for the first tumour. We therefore examined biopsy specimens from the contralateral testis in consecutive patients with germ-cell tumours and report here our experience with the first 50 patients.

\section{Patients and methods}

Twenty-one men with seminoma (median age 32 years) and 29 with other germinal cancers (median age 29 years) were studied. All were treated at hospitals in or near Copenhagen in 1972-9. During the first six years of this period only one surgical department participated but during the last year more departments have joined the study. From the time of joining the study each department has offered to take a biopsy specimen from the contralateral testicle in all patients with germinal testicular cancer. Five men declined to have the procedure performed. In one other case the tumour was of nongerminal origin and this patient was not included in the study. In no case was neoplasia of the contralateral testis suspected clinically at the time of biopsy.

The biopsy specimens were removed surgically either during general anaesthesia for the orchiectomy of the cancerous testicle or

\footnotetext{
Laboratory of Reproductive Biology and Fertility Clinic, University Department of Obstetrics and Gynaecology, YA, Rigshospitalet, Copenhagen

JØRGEN G BERTHELSEN, MD, research fellow

\begin{abstract}
University Department of Obstetrics and Gynaecology, Herlev Hospital, Copenhagen

NIELS E SKAKKEBAEK, MD, DRMED, consultant physician
\end{abstract}

University Department of Urology H, Herlev Hospital, Copenhagen PETER MOGENSEN, MD, DRMED, senior registrar

Department of Surgery, Finsen Institute, Copenhagen, Denmark BENT L SØRENSEN, MD, DRMED, chief surgeon under local anaesthesia during the interval between orchiectomy and radiotherapy. Tissue specimens of 3 to $4 \mathrm{~mm}$ in diameter were fixed in Cleland's ${ }^{7}$ or Stieve's fixative, ${ }^{8}$ dehydrated in alcohol, and embedded in Paraplast. The 4- $\mu \mathrm{m}$ serial sections were stained with ironhaematoxylin and eosin. ${ }^{7}$ Microscopy was performed using a Zeiss microscope with a $\times 40$ objective lens and $\times 12.5$ eye-pieces. Randomly chosen sections were studied. At least eight different sections with an interval of at least $40 \mu \mathrm{m}$ were examined.

\section{Results}

In three of the 21 men with seminomas and one of 29 with other germinal cancers a carcinoma in situ pattern (fig) was found $(8 \%$, $95 \%$ confidence limits $2 \cdot 2-19 \cdot 2$ ). One of the four men developed early

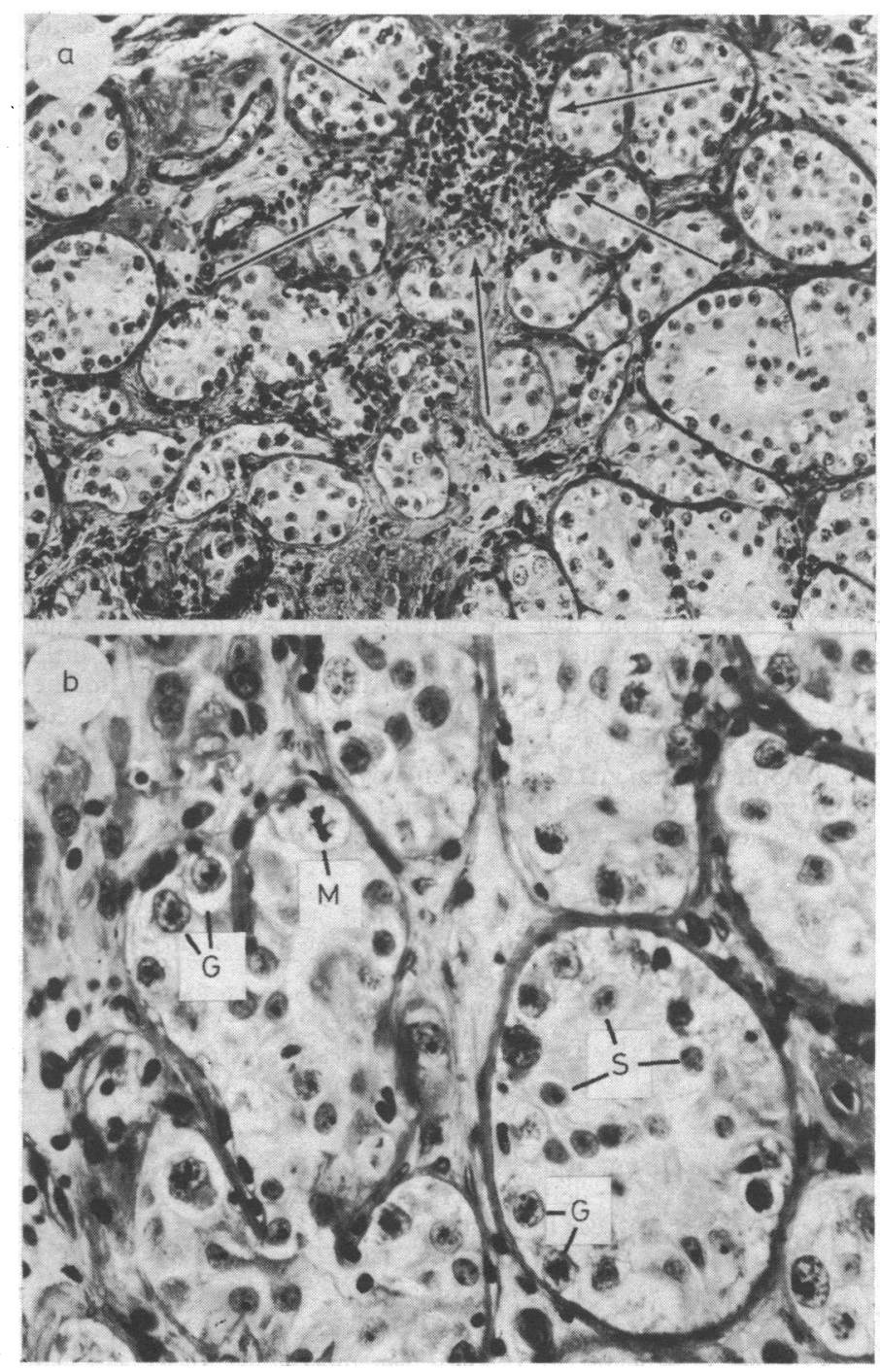

(a) Carcinoma in situ of contralateral testis in patient with germinal testicular tumour. All seminiferous tubules contain large atypical germ cells and Sertoli cells of normal morphology. Aggregation of lymphocytes is arrowed. Iron-haematoxylin and eosin. $\times 150$ (original magnification). (b) Higher magnification of same specimen showing atypical germ cells (G), Sertoli cells (S), mitosis (M). Iron-haematoxylin and eosin. $\times 600$ (original magnification). 
invasive germinal cancer 46 months after carcinoma in situ was first diagnosed (previously described as case 4 in ref $^{5}$ ). The remaining three men have been followed up for less than one year without signs of tumour growth.

In 42 of the remaining 46 sets of biopsy specimens spermatogenesis was found in all or nearly all of the tubules. In the other four sets of specimens various degrees of spermatogenic failure but no malignant changes were found.

\section{Discussion}

Our results showed that carcinomas in situ of the germ cells were present in the contralateral testis of $8 \%$ of men operated on for clinically unilateral testicular germ-cell tumours. Although the incidence of bilateral testicular cancer in Denmark is unknown, investigators from other countries have found that $1-2 \%$ of men with germinal cancer develop cancer of the contralateral testis as well. ${ }^{2} 910$ Nevertheless, no systematic search for premalignant changes has been performed. Many of the published reports were made at a time when the prognosis of testicular cancer was so poor that many patients did not survive long enough to allow the second tumour to develop. Moreover, systematic long-term follow-up of the reported cases seems to have been lacking.

Denmark has the highest known incidence of testicular tumours, and a sharp increase in morbidity from these neoplasms has occurred during the last 30-40 years. ${ }^{11}$ Whether this influences the incidence of bilateral tumours is not known. Infertile men with carcinomas in situ in their testes apparently have a probability of $70 \%$ of developing invasive neoplasia within five years. ${ }^{12}$ The same relationship may exist between carcinoma in situ and invasive tumour growth in the contralateral testis of patients with germinal testicular tumours. If the high incidence of carcinoma in situ is confirmed routine biopsy of the contralateral testis may be indicated in patients with germinal testicular cancer.

We thank the participating surgical departments for their help in obtaining the biopsies; Professor J Visfeldt for his help; Dr K HouJensen for providing some of the histological material; and Mrs Annelise Persson and Mrs Elsebeth Sønderup for their expert technical help.

\section{References}

${ }^{1}$ Morris, S A, Vaughan, E D, and Constable, W C, fournal of Urology, 1976, $115,556$.

2 Pugh, R C B, in Pathology of the Testis, ed R C B Pugh. Oxford, Blackwell, 1976.

${ }^{3}$ Skakkebaek, N E, Acta Pathologica Microbiologica Scandinavica, A, 1972, $80,374$.

4 Skakkebaek, N E, Lancet, 1972, 2, 516.

5 Skakkebaek, N E, Histopathology, 1978, 2, 157.

6 Nüesch-Bachmann, I H, and Hedinger, C, Schweizerische Medizinische Wochenschrift, 1977, 107, 795.

${ }^{7}$ Rowley, M J, and Heller, C G, Fertility and Sterility, 1966, 17, 177.

${ }^{8}$ Lillie, R D, and Fullmer, H M, Histopathologic Technic and Practical Histochemistry, 4th edn. New York, McGraw-Hill, 1976.

9 Hamilton, J B, and Gilbert, J B, Cancer Research, 1942, 2, 125.

${ }^{10}$ Blandy, J P, Hope-Stone, H F, and Dayan, A D, Tumours of the Testicle. London, Heinemann, 1970.

${ }^{11}$ Clemmesen, J, Acta Pathologica Microbiologica Scandinavica, A, 1969, suppl No 209.

12 Skakkebaek, N E, and Berthelsen, J G, Lancet, 1978, 2, 204.

(Accepted 28 fune 1979)

\section{SHORT REPORTS}

\section{Effect of calcitonin on deafness due to Paget's disease of skull}

Deafness is a common and distressing complication of Paget's disease that develops in about half the patients diagnosed as having skull disease. ${ }^{1}$ The natural history of Pagetoid deafness has been little studied; it is assumed to progress and in some way relate to the severity of the Paget's disease. Until recently treatment was limited, as surgery is of doubtful benefit. ${ }^{2}$

Calcitonin treatment is often effective in relieving pain and improving the biochemical abnormalities of Paget's disease, although the complications of deformity and deafness have not been clearly
The table summarises the results of the pure-tone audiograms. The air-bone gaps (in $\mathrm{dB}$ ) at $250,500,1000,2000$, and $4000 \mathrm{~Hz}$ of both left and right ears were added together on each audiogram for every patient. The change in this total from the first audiogram was calculated as an index of conductive change. A positive figure indicates an increase in the size of the gap and thus increasing deafness. Similarly, a total change in air conduction at 2000,4000 , and $8000 \mathrm{~Hz}$ was calculated as an index of the high-frequency sensorineural component of deafness.

The table shows the mean change in total air-bone gap and high-frequency loss for each patient. Statistical analysis using a non-paired $t$ test showed no discernible difference between the treated and untreated groups. In particular, the three patients receiving long-term calcitonin did not show any specific benefit. The mean changes in the total air-bone gap and total high-frequency loss were respectively $+265 \mathrm{~dB}$ and $+48 \mathrm{~dB}$ in the untreated group compared with $+6.4 \mathrm{~dB}$ and $+84 \mathrm{~dB}$ in the untreated group. The

Mean changes in total air-bone gap and in total high-frequency loss in all patients over three-year follow-up

\begin{tabular}{|c|c|c|c|c|c|c|c|c|}
\hline $\begin{array}{l}\text { Control group } \\
\text { Treated group }\end{array}$ & $\left\{\begin{array}{l}\text { Air-bone gap (dB) } \\
\text { High-frequency loss (dB) } \\
\text { Air-bone gap (dB) } \\
\text { High-frequency loss (dB) }\end{array}\right.$ & $\begin{array}{r}+50 \\
0 \\
-170 \\
+160\end{array}$ & $\begin{array}{r}-130 \\
+\quad 0 \\
+450 \\
+1025\end{array}$ & $\begin{array}{r}+1135 \\
+270 \\
-690 \\
-515\end{array}$ & $\begin{array}{r}+495 \\
+80 \\
+130 \\
-115\end{array}$ & $\begin{array}{r}+215 \\
-65 \\
+175 \\
-25\end{array}$ & $\begin{array}{r}-175 \\
+5 \\
-35 \\
-25\end{array}$ & $\begin{array}{r}+185 \\
+85\end{array}$ \\
\hline
\end{tabular}

shown to benefit. In an earlier report we presented evidence suggesting a possible benefit from calcitonin in Pagetoid deafness. ${ }^{3}$ We now report the results of a three-year follow-up of these patients.

\section{Patients, methods, and results}

We studied 13 patients with deafness over three years. All patients had radiological evidence of skull disease, subjective evidence of deafness, and both low-tone conductive loss and high-tone sensorineural loss on a puretone audiogram. Seven patients received calcitonin and six no calcitonin (control group). The patients receiving continuous calcitonin all had facial deformity and were prescribed calcitonin in the hope that it would arrest this progressive deformity. The remaining patients were prescribed intermittent courses of calcitonin to relieve pain. mean changes for the three patients who received continuous calcitonin were $-136 \mathrm{~dB}$ and $+223 \mathrm{~dB}$. Again no significant difference exists between these values and those in the control group.

The data also show the small overall changes that occurred in treated and untreated groups over the three years.

\section{Comment}

In $1977^{3}$ we suggested that the progression of Pagetoid deafness may be delayed by calcitonin. Others ${ }^{4}$ have also reported similar findings. Grimaldi et $a l,{ }^{5}$ however, failed to show any change in hearing when patients were given calcitonin. The present series shows no obvious benefit from calcitonin treatment over three years. 